\title{
ANALISIS KUALITAS LAYANAN DAN MOTIVASI YANG MEMPENGARUHI KEPUTUSAN KONSUMEN DALAM MENABUNG PADA BANK BNI
}

\section{Koesharijadi}

Sekolah Tinggi Ilmu Ekonomi Mitra Indonesia

Email: koesharijadi69@gmail.com

\section{Abstract}

This study is aimed at, among others, providing a picture of the quality service and motivation, as well the decision made by customers in general. Knowing the influence of motivation and service quality on the customer's decision to save. The study was conducted at the Bank Negara Indonesia, Pasuruan. The population of this study comprised civil government officials having an account at the bank under investigation. One hundred and forty (140) customers were used as samples. Multiple linear regression analysis with microstat statistic programming was used. The results of the study indicate that (1) motivation to have significant influence in consumer decision to save, (2) service quality to have significant influence in consumer decision to save, (3) motivation and service quality played a significant role in consumer decision to save

Keywords: Quality service, Motivation, Consumer decision to save

\begin{abstract}
Abstrak
Penelitian ini bertujuan, antara lain, memberikan gambaran tentang kualitas layanan dan motivasi, serta keputusan yang dibuat oleh pelanggan pada umumnya. Mengetahui pengaruh motivasi dan kualitas layanan pada keputusan pelanggan untuk menabung. Penelitian dilakukan di Bank Negara Indonesia, Pasuruan. Populasi penelitian ini terdiri dari pejabat pemerintah sipil yang memiliki rekening di bank yang sedang diselidiki. Seratus empat puluh (140) pelanggan digunakan sebagai sampel. Analisis regresi linier berganda dengan pemrograman statistik microstat digunakan. Hasil penelitian menunjukkan bahwa (1) motivasi memiliki pengaruh yang signifikan dalam keputusan konsumen untuk menabung, (2) kualitas layanan memiliki pengaruh yang signifikan dalam keputusan konsumen untuk menabung, (3) motivasi dan kualitas layanan memainkan peran penting dalam keputusan konsumen. untuk menyimpan.
\end{abstract}

Kata kunci: Kualitas layanan, Motivasi, Keputusan konsumen untuk menabung

\section{Pendahuluan}

Perbankan didirikan sebagai organisasi yang berorientasi pada profit (profit oriented), maka tantangan bagi pertumbuhan perbankan terletak pada pembinaan manajemen, peningkatan kualitas layanan (service quality) dan bagaimana perbankan tersebut dalam memahami keinginan, harapan dan kebutuhan masyarakat yang terkait 
mengapa mereka termotivasi mau menginvestasikan dananya pada perbankan. Motivasi masyarakat terkait mengapa mereka mau menginvestasikan dananya pada perbankan tidak terlepas dari keinginannya untuk memperoleh berbagai keuntungan atau manfaat yang akan mereka dapat. Motif merupakan suatu ransangan keinginan dan daya penggerak seseorang, setiap motif mempunyai tujuan tertentu yang ingin dicapai (Hasibuan, 2002).

Motivasi adalah daya dorong yang dimiliki seseorang untuk mencapai dan/atau melakukan apa yang ingin dia lakukan. Apabila dikaitkan dengan belajar, maka Pengembangan Model Jerold melalui Kartu Kalimat motivasi belajar dapat diartikan sebagai suatu dorongan dan/atau upaya yang dilakukan seseorang untuk belajar dengan lebih baik dibanding tidak memiliki motivasi (Saputro \& Soeharto, 2015). Analisis motivasi memusatkan perhatian pada faktor-faktor yang mendorong dan mengarahkan kegiatan seseorang (Mills \& Hatfield, 1999). Perbankan harus memahami motivasi ini sehingga mendapatkan pemahaman yang baik mengapa masyarakat berperilaku tertentu dalam membeli suatu produk yang ditawarkan. Keberadaan motivasi mengacu pada timbulnya kebutuhan dalam artian tanpa adanya kebutuhan tidak akan ada motivasi. Konsumen mau menginveskan dananya pada perbankan dalam rangka untuk memenuhi kebutuhannya yang diyakini akan memberikan beberapa manfaat. Masing-masing perbankan mempunyai produk dengan karakterisik manfaat yang ditawarkan berbedabeda. Beberapa manfaat yang ditawarkan perbankan ini akan memotivasi masyarakat untuk mendapatkan manfaat tersebut. Motivasi ini ada yang bersifat ekonomis (motivasi ekonomis), keamanan dana (motivasi keamanan), manfaat praktis (motivasi praktis) dan motivasi emosional. Dorongan yang berbeda akan menyebabkan tingkah laku yang berbeda pula.

Keempat sifat motivasi ini dapat mempengaruhi pertimbangan masyarakat dalam tingkat yang berbeda, mengapa mereka mau menginvestasikan dana pada perbankan. Kebutuhan yang berbeda akan menjadi tanggapan yang berbeda atas stimuli karena kebutuhan akan menentukan perilaku sehingga mendorong (motivator) dalam menentukan pilihan diantara berbagai alternatif sesuai dengan kebutuhan. Pemahaman tentang keempat motivasi tersebut akan membantu pihak perbankan dalam mengambil kebijakan tentang produk yang ditawarkan dengan dukungan promosi yang tetap.

Pemahaman tentang motivasi masyarakat mengapa mereka menginvestasikan dana pada perbankan merupakan "pekerjaan" perbankan yang bersifat eksternal. Bagian internal perbankan (kualitas layanan) perlu diwujudkan perbankan untuk memberikan pelayanan terbaik bagi nasabah. Beberapa hal yang perlu diperhatikan dalam mewujudkan kualitas layanan yang baik pada industri jasa khususnya perbankan. Pertama, kemampuan kontak personil yaitu perhatian terhadap individu (empathy) yang terwujud dalam hubungan yang baik dan pemahaman yang mendalam terhadap individu nasabah. Kedua, kepercayaan masyarakat terhadap perbankan (reliability) yaitu kemampuan dalam memenuhi kesepakatan-kesepakatan dan "janji-janji” dalam program promosi yang pernah dilakukan. Ketiga, ketersedianya dan berfungsinya berbagai fasilitas fisik (tampilan fisik) sebagai penunjang sistem layanan yang 
representatif bagi karyawan dan nasabah. Dimensi tangibility berhubungan langsung dengan fasilitas fisik, penampilan, peralatan personil (Hardiyansyah, 2018).

Kualitas layanan merupakan ukuran penilaian menyeluruh atas tingkat layanan yang baik (Parasuraman et al., 1985). Kualitas layanan yang diwujudkan oleh organisasi (perbankan) merupakan daya tarik setelah nasabah melakukan evaluasi (membandingkan) antara harapan sebelum mendapatkan pelayanan dengan kinerja layanan yang sebenarnya. Antar perbankan tentu terjadi persaingan yang ketat dalam memberikan pelayanan yang terbaik bagi nasabah. Sistem manajemen kinerja adalah merupakan suatu hal yang sangat penting untuk mengkomunikasikan, memotivasi dan memberikan balas jasa kepada karyawan yang mendukung terwujudnya tujuan-tujuan bisnis. Penyesuaian-penyesuaian rencana insentif dengan tujuan-tujuan bisnis agar mendukung perilaku menuju kinerja yang lebih baik. Pada sisi yang lain perbankan berusaha menghimpun dana yang sebanyak-banyaknya dari masyarakat, sehingga dikwatirkan banyak networking dari perbankan yang hanya didasarkan pada mutual benefit dan kurang perhatian pada mutual respect (Koesharijadi, 2016). Kelemahan fundamental dari sisi internal perbankan itu terutama dalam penerapan good corporate governance yang diwarnai dengan kualitas manajemen bank yang masih buruh. Manajemen kurang memiliki komitmen pada sistem kualitas, kurangnya pengetahuan tentang konsep kualitas, kurangnya pemahaman tentang prioritas dalam penerapan sistem kualitas dan budaya kerja yang baik. Kualitas layanan yang baik mencerminkan jalannya organisasi yang efektif, memahami lingkungan, hubungan baik dengan masyarakat tanpa diskriminasi (Koesharijadi, 2017).

\section{Metode Penelitian}

Penelitian ini merupakan explanatory research. Populasi penelitian ini Pegawai Negeri Sipil. Karakteristik sampel yang diuji adalah PNS yang hanya menjadi nasabah pada satu bank BNI. Pengambilan sampel secara acak (random sampling) karena sampel diprediksi mampu merepresentasikan populasi dan mengerti topik yang diteliti. Pengumpulan data menggunakan kuesioner, wawancara dan studi dokumen. Penentuan skor untuk item pernyataan menggunakan skala Likert, dengan skor 5 (lima), 4 (empat), 3 (tiga), 2 (dua) dan 1 (satu) dengan gradasi sangat positif sampai sangat negatif. Data penelitian data primer dan data sekunder.

\section{Hasil dan Pembahasan}

Jenis kelamin responden sebagian besar adalah pria $(67,86 \%)$. Usia responden sebagian besar antara 35 sampai 45 tahun $(60,70 \%)$. Tingkat pendidikan responden sebagian besar SMA (77,86\%). Tingkat penghasilan responden sebagian besar antara Rp. 1.000.000 sampai Rp. 2.000 .000 (68,09\%). Sebagian besar menjadi nasabah selama lebih dari 3 tahun $(61,42 \%)$. 


\section{Pengaruh motivasi terhadap keputusan konsumen dalam menabung (H1)}

Berdasarkan uji pengaruh variabel motivasi (X1) terhadap variabel keputusan konsumen dalam menabung (Y), mempunyai multiple regression sebesar 0,7769 maka dapat dikatakan hubungan tersebut cukup kuat dan hal ini juga ditunjukkan dengan koefisien determinasi sebesar 0,5918\%. Hal ini artinya bahwa kontribusi motivasi terhadap keputusan konsumen dalam menabung sebesar $59,18 \%$ dan sisanya dipengaruhi oleh variabel lain diluar penelitian ini. Berdasarkan uji $\mathrm{F}$ terlihat bahwa nilai $\mathrm{F}$ hitung sebesar 51,370. Nilai $\mathrm{F}$ hitung ini lebih besar jika dibandingkan dengan nilai $\mathrm{F}$ tabel sebesar 1,94 dengan nilai probabilitas sebesar 0,000. Dengan dimikian hipotesis yang menyatakan "Ada pengaruh motivasi terhadap keputusan konsumen dalam menabung" dinyatakan dapat diterima.

Tabel 1

Rekapitulasi hasil regresi variabel motivasi (X1) dengan variabel keputusan konsumen dalam menabung $(\mathbf{Y})$

\begin{tabular}{|c|c|c|c|c|c|}
\hline $\begin{array}{c}\text { Variabel } \\
\text { bebas }\end{array}$ & $\begin{array}{c}\text { Koefisien } \\
\text { regresi }\end{array}$ & $\begin{array}{c}\mathrm{t} \\
\text { hitung }\end{array}$ & Prob. & $\begin{array}{c}\mathrm{r} \\
\text { partial }\end{array}$ & Ket. \\
\hline M. Ekonomis & 0,3909 & 10,2690 & 0,0000 & 0,4386 & diterima \\
\hline M. Keamanan & 0,2067 & 2,6790 & 0,0083 & 0,5105 & diterima \\
\hline M. Praktis & 0,2788 & 2,5810 & 0,0192 & 0,4270 & diterima \\
\hline M. Emosional & $-0,0224$ & $-0,9090$ & 0,3647 & 0,0261 & ditolak \\
\hline \multicolumn{6}{|c|}{ Variabel tergantung Y } \\
\hline \multicolumn{3}{|c|}{ Konstanta } & \multicolumn{2}{|c|}{ Probabilitas } & $=0,0000$ \\
\hline F hitung & \multicolumn{2}{|c|}{51,370} & \multicolumn{2}{|c|}{ Adj. R Squared } & $=0,6918$ \\
\hline F tabel & \multicolumn{2}{|c|}{1,94} & \multicolumn{2}{|c|}{ R Squared } & $=0,6835$ \\
\hline t tabel & \multicolumn{2}{|c|}{1.65} & \multicolumn{2}{|c|}{ Multiple R } & $=0,7769$ \\
\hline
\end{tabular}

2. Pengaruh motivasi ekonomis terhadap keputusan konsumen dalam menabung (H1.1)

Berdasarkan uji pengaruh variabel motivasi ekonomis (X1.1) terhadap variabel keputusan konsumen dalam menabung (Y), mempunyai nilai Prob. 0,0000 dan nilai r sebesar 0,4386 maka dapat ditarik kesimpulan bahwa hipotesis: "Ada pengaruh motivasi ekonomis terhadap keputusan konsumen dalam menabung" dapat diterima.

3. Pengaruh motivasi keamanan terhadap keputusan konsumen dalam menabung (H1.2)

Berdasarkan uji pengaruh variabel motivasi keamanan (X1.2) terhadap variabel keputusan konsumen dalam menabung (Y), mempunyai nilai Prob. 0,0083 dan nilai $\mathrm{r}$ sebesar 0,5105 . Selanjutnya dapat ditarik kesimpulan bahwa hipotesis: "Ada pengaruh motivasi keamanan terhadap keputusan konsumen dalam menabung" dapat diterima. 
4. Pengaruh motivasi praktis terhadap keputusan konsumen dalam menabung (H1.3)

Berdasarkan uji pengaruh variabel motivasi praktis (X1.3) terhadap variabel keputusan konsumen dalam menabung (Y), mempunyai nilai Prob. 0,0192 dan nilai r sebesar 0,4270. Selanjutnya dapat ditarik kesimpulan bahwa hipotesis: "Ada pengaruh motivasi praktis terhadap keputusan konsumen dalam menabung" dapat diterima.

5. Pengaruh motivasi emosional terhadap keputusan konsumen dalam menabung (H1.4)

Berdasarkan uji pengaruh variabel motivasi emosional (X1.4) terhadap variabel keputusan konsumen dalam menabung (Y), mempunyai nilai Prob. 0,3647 dan nilai $r$ sebesar 0,0261 . Selanjutnya dapat ditarik kesimpulan bahwa hipotesis: "Ada pengaruh motivasi emosional terhadap keputusan konsumen dalam menabung" ditolak.

6. Pengaruh kualitas layanan terhadap keputusan konsumen dalam menabung (H2)

Berdasarkan uji pengaruh variabel kualitas layanan (X2) terhadap variabel keputusan konsumen dalam menabung $(\mathrm{Y})$, mempunyai multiple regression sebesar 0,7697, maka dapat dikatakan hubungan tersebut cukup kuat dan hal ini juga ditunjukkan dengan koefisien determinasi sebesar 0,5835\%. Artinya bahwa kontribusi kualitas layanan terhadap keputusan konsumen dalam menabung sebesar $58,35 \%$ dan sisanya dipengaruhi oleh variabel lain diluar penelitian ini. Berdasarkan uji F terlihat bahwa nilai F hitung sebesar 65,908. Nilai F hitung ini lebih besar jika dibandingkan dengan nilai $F$ tabel sebesar 1,94 dan nilai probabilitasnya sebesar 0,000. Dengan dimikian hipotesis yang menyatakan "Ada pengaruh kualitas layanan terhadap keputusan konsumen dalam menabung" dinyatakan dapat diterima.

\section{Tabel 2}

Rekapitulasi hasil regresi variabel kualitas layanan (X2) dengan variabel keputusan konsumen dalam menabung (Y)

\begin{tabular}{|c|c|c|c|c|c|}
\hline $\begin{array}{c}\text { Variabel } \\
\text { bebas }\end{array}$ & $\begin{array}{c}\text { Koefisien } \\
\text { regresi }\end{array}$ & $\begin{array}{c}\mathrm{t} \\
\text { hitung }\end{array}$ & Prob. & $\begin{array}{c}\mathrm{r} \\
\text { partial }\end{array}$ & Ket. \\
\hline Perht.Individu & 0,2862 & 2,5930 & 0,0105 & 0,4071 & diterima \\
\hline Kepercayaan & 0,4541 & 11,8000 & 0,0000 & 0,5059 & diterima \\
\hline Tampilan Fisik & 0,0299 & 1,0930 & 0,2763 & 0,0087 & ditolak \\
\hline \multicolumn{6}{|c|}{ Jariabel tergantung Y } \\
\hline \multicolumn{3}{|c|}{ Konstanta } & \multicolumn{2}{|c|}{ Probabilitas } & $=0,0000$ \\
\hline F hitung & \multicolumn{2}{|c|}{65,908} & \multicolumn{2}{|c|}{ Adj. R Squared } & $=0,5835$ \\
\hline F tabel & \multicolumn{2}{|c|}{1,94} & \multicolumn{2}{|c|}{ R Squared } & $=0,5925$ \\
\hline $\mathrm{t}$ tabel & \multicolumn{2}{|c|}{1,65} & \multicolumn{2}{|c|}{ Multiple R } & $=0,7697$ \\
\hline
\end{tabular}


7. Pengaruh kualitas layanan dari perhatian individu terhadap keputusan konsumen dalam menabung (H2.1)

Berdasarkan uji pengaruh variabel kualitas layanan dari perhatian individu (X2.1) terhadap variabel keputusan konsumen dalam menabung (Y), mempunyai nilai Prob. 0,0105 dan nilai r sebesar 0,4071. Selanjutnya dapat ditarik kesimpulan bahwa hipotesis: "Ada pengaruh kualitas layanan dari perhatian individu terhadap keputusan konsumen dalam menabung" dapat diterima.

8. Pengaruh kualitas layanan dari kepercayaan terhadap keputusan konsumen dalam menabung (H2.2)

Berdasarkan uji pengaruh variabel kualitas layanan dari kepercayaan (X2.2) terhadap variabel keputusan konsumen dalam menabung (Y), mempunyai nilai Prob. 0,0000 dan nilai $r$ sebesar 0,5059. Selanjutnya dapat ditarik kesimpulan bahwa hipotesis: "Ada pengaruh kualitas layanan dari kepercayaan terhadap keputusan konsumen dalam menabung" dapat diterima.

9. Pengaruh kualitas layanan dari tampilan fisik terhadap keputusan konsumen dalam menabung (H2.3)

Berdasarkan uji pengaruh variabel kualitas layanan dari tampilan fisik (X2.3) terhadap variabel keputusan konsumen dalam menabung (Y), mempunyai nilai Prob. 0,2763 dan nilai r sebesar 0,0087. Selanjutnya dapat ditarik kesimpulan bahwa hipotesis: "Ada pengaruh kualitas layanan dari tampilan fisik terhadap keputusan konsumen dalam menabung" ditolak.

10. Pengaruh motivasi dan kualitas layanan terhadap keputusan konsumen dalam menabung (H3)

Berdasarkan uji pengaruh variabel motivasi (X1) dan variabel kualitas layanan (X2) terhadap variabel keputusan konsumen dalam menabung (Y), mempunyai multiple regression sebesar 0,8391, maka dapat dikatakan hubungan tersebut cukup kuat dan hal ini juga ditunjukkan dengan koefisien determinasi sebesar $0,6884 \%$. Hal ini artinya bahwa kontribusi motivasi terhadap keputusan konsumen dalam menabung sebesar $68,84 \%$ dan sisanya dipengaruhi oleh variabel lain diluar penelitian ini. Berdasarkan uji $\mathrm{F}$ terlihat bahwa nilai $\mathrm{F}$ hitung sebesar 44,874 . Nilai $F$ hitung ini lebih besar jika dibandingkan dengan nilai $F$ tabel sebesar 1,94 dengan nilai probabilitas sebesar 0,000. Dengan dimikian hipotesis yang menyatakan "Ada pengaruh motivasi dan kualitas layanan terhadap keputusan konsumen dalam menabung" dapat diterima.

Tabel 3

Rekapitulasi hasil regresi variabel motivasi (X1) dan kualitas layanan (X2) dengan variabel keputusan konsumen dalam menabung $(\mathbf{Y})$

\begin{tabular}{lcll} 
Konstanta & 10,2522 & Probabilitas & $=0,0000$ \\
F hitung & 44,874 & Adj. R Squared & $=0,6884$ \\
F tabel & 1,94 & R Squared & $=0,7041$ \\
t tabel & 1,65 & Multiple R & $=0,8391$ \\
\hline
\end{tabular}


Motivasi adalah sampai seberapa tingkat seseorang menabung karena didorong untuk memperoleh berbagai manfaat dari sisi ekonomis, keamanan, praktis dan emosional. Dari sisi motivasi ekonomis berdasarkan dari 5 item yang disediakan untuk 140 responden, sebagian besar yaitu sebanyak 119 responden (85\%), menyatakan bahwa mereka menabung karena didorong untuk mendapat hasil bunga dari uang yang diinvestasikan. Maka kesimpulannya adalah keputusan konsumen dalam menabung karena ingin mendapatkan bunga. Bunga bank merupakan faktor pendorong utama untuk mendapatkan manfaat ekonomis sebagai balas jasa dari dana yang diinvestasikan pada perbankan.

Dari sisi motivasi keamanan berdasarkan dari 5 item yang disediakan untuk 140 responden, sebagian besar yaitu sebanyak 113 responden (80,9\%), menyatakan bahwa mereka menabung karena didorong oleh motivasi keamanan. Maka kesimpulannya adalah keputusan konsumen dalam menabung karena ingin mendapatkan keamanan dari uang yang tersimpan pada bank. Faktor keamanan dana merupakan pertimbangan yang utama bagi nasabah untuk menginvestasikan dananya pada perbankan yang dilihat dari motivasi keamanan.

Pada sisi motivasi praktis berdasarkan dari 5 item yang disediakan untuk 140 responden, sebagian besar yaitu sebanyak 89 responden $(63,5 \%)$, menyatakan bahwa mereka menabung karena didorong oleh motivasi praktis dari sisi fasilitas on-line. Maka kesimpulannya adalah keputusan konsumen dalam menabung karena ingin mendapatkan manfaat praktis dari uang yang tersimpan pada bank dapat diambil kapanpun dan dimanapun, karena bank memberikan pelayanan fasilitas online diseluruh cabang.

Dari sisi motivasi emosional berdasarkan dari 5 item yang disediakan untuk 140 responden, sebagian besar yaitu sebanyak 61 responden (44,0\%), menyatakan bahwa mereka menabung karena didorong oleh motivasi emosional untuk mendapatkan hadiah. Maka kesimpulannya adalah keputusan konsumen dalam menabung karena ingin mendapatkan hadiah dari uang yang tersimpan pada bank. Berbagi hadiah yang dapat ditawarkan dan dipamerkan oleh perbankan selama ini ternyata kurang cukup menarik konsumen perbankan untuk menginvestasikan dananya.

Selanjutnya berdasarkan uji yang dilakukan terlihat bahwa diantara keempat motivasi yang menunjukkan memiliki pengaruh terbesar yang mendorong keputusan konsumen dalam menabung adalah motivasi ekonomis yang ditunjukkan dengan nilai r partial sebesar 0,4386. Sedangkan urutan berikutnya konsumen melakukan kegiatan menabung karena didorong motivasi praktis. Hasil yang cukup menarik ternyata bahwa konsumen perbankan dalam menginvestasikan dananya bukan karena terdorong oleh motivasi emosional. Hal ini ditunjukkan dari hasil uji yang dilakukan menunjukkan bahwa nilai $r$ partial untuk motivasi emosional terhadap keputusan untuk menabung hanya sebesar 0,0061. Hal ini dapat disimpulkan bahwa yang mendorong konsumen perbankan untuk menginvestasikan dananya (menabung) pada bank karena ingin mendapatkan manfaat ekonomis dan 
praktis yang diberikan oleh perbankan, bukan karena ingin mendapatkan manfaat secara emosional.

\section{Kesimpulan}

Berdasarkan hasil analisis regresi linier berganda dapat diketahui bahwa motivasi mempunyai pengaruh yang signifikan terhadap keputusan konsumen dalam menabung yang ditunjukkan dengan multiple regression 0,7769 dan $\mathrm{F}$ hitung sebesar 51,370 lebih besar dari nilai $\mathrm{F}$ tabel sebesar 1,94. Hal ini berarti motivasi mempunyai pengaruh yang signifikan terhadap keputusan konsumen dalam menabung pada taraf uji sebesar 5\%. Sehingga hipotesis yang menyatakan "Ada pengaruh motivasi terhadap keputusan konsumen dalam menabung" dapat diterima.

Analisis regresi linier berganda selanjutnya adalah untuk mengetahui pengaruh kualitas layanan terhadap keputusan konsumen dalam menabung dapat ditunjukkan dengan nilai multiple regression sebesar 0,7697 . Selanjutnya dapat diketahui nilai $\mathrm{F}$ hitung sebesar 65,908 lebih besar dari nilai $\mathrm{F}$ tabel sebesar 1,94, maka dapat dikatakan bahwa kualitas layanan berpengaruh secara signifikan terhadap keputusan konsumen dalam menabung pada taraf signifikansi sebesar 5\%. Maka dapat diambil kesimpulan bahwa hipotesis yang menyatakan "Ada pengaruh kualitas layanan terhadap keputusan konsumen dalam menabung" dapat diterima.

Berdasarkan uji bersama-sama dengan analisis regresi linier berganda dapat ditunjukkan bahwa motivasi dan kualitas layanan mempunyai pengaruh yang cukup kuat dengan nilai multiple regression sebesar 0,8391 dengan nilai $\mathrm{F}$ hitung sebesar 44,874 lebih besar dari nilai $\mathrm{F}$ tabel sebesar 1,94. Hal ini berarti mempunyai pengaruh yang signifikan pada taraf signifikansi sebesar 5\%. Sehingga hipotesis yang menyatakan "Ada penganuh motivasi dan kualitas layanan terhadap keputusan konsumen dalam menabung" dapat diterima.

Variabel pilihan berdasarkan nilai loading tertinggi pada masing-masing faktor yang mempengaruhi keputusan konsumen dalam menabung yaitu:

a. Bank yang mempunyai kredibilitas dan likuiditas keuangan yang baik, dapat disimpulkan bank tersebut memiliki tingkat kepercayaan (reliability) yang baik dimata masyarakat dalam memberikan pelayanan. Kepercayaan (reliability) dalam pelayanan ini mempunyai pengaruh yang paling dominan terhadap pengambilan keputusan konsumen dalam menabung.

b. Motivasi konsumen yang paling dominan berpengaruh untuk menanamkan uangnya ke bank adalah untuk mendapatkan hasil bunga, hal ini dikelompokkan kedalam motivasi ekonomis.

c. Pertimbangan menabung untuk keamanan uang yang disimpan, dikelompokkan kedalam motivasi keamanan.

d. Bank yang dapat memberikan layanan sepenuh hati terhadap berbagai kepentingan dan keperluan konsumen, dikelompokkan kedalam kualitas layanan dalam hal perhatian individu (empathy). 
Koesharijadi

e. Adanya fasilitas on-line antar berbagai wilayah cabang bank hal ini mempengaruhi keputusan konsumen dalam menabung dikelompokkan kedalam motivasi untuk memperoleh manfaat praktis. 
Analisis Kualitas Layanan dan Motivasi yang Mempengaruhi Keputusan Konsumen

\section{BIBLIOGRAFI}

Hardiyansyah, K. \&. (2018). Public Service Quality of the Tax Service Office of Pratama Palembang: Qualitative Study of Taxpayer Service. Humanities and Social Sciences. http://saspjournals.com/sjahss

Hasibuan, M. (2002). Manajemen Sumber Daya Manusia. Edisi Revisi. Cetakan keenam. Jakarta: Bumi Aksara.

Koesharijadi. (2016). Factors Affecting Loyalty Customer Services Banking Industry in East Java. International Journal of Business and Management, 11(6), 177.

Koesharijadi, H. \& S. (2017). Improving the Quality of Public Services Based on Information Technology through Development of Human Resources Management in Palembang. Journal of Public Administration and Governance, 7(4). https://doi.org/10.5296/jpag.v7i4.11857. http://jpag.macrothink.org

Mills, A. J., \& Hatfield, J. (1999). From imperialism to globalization: Internationalization and the management text. Global Management: Universal Theories and Local Realities, 37-67.

Parasuraman, A., Zeithaml, V. A., \& Berry, L. L. (1985). A conceptual model of service quality and its implications for future research. Journal of Marketing, 49(4), 4150 .

Saputro, H. B., \& Soeharto, S. (2015). Pengembangan media komik berbasis pendidikan karakter pada pembelajaran tematik-integratif kelas IV SD. Jurnal Prima Edukasia, 3(1), 61-72. 